\title{
Virulence Dynamics and Regional Structuring of Puccinia striiformis f. sp. tritici in France Between 1984 and 2009
}

\author{
Claude de Vallavieille-Pope, Sajid Ali, and Marc Leconte, UMR 1290 BIOGER-CPP, INRA-AgroParisTech, BP01, 78850 Thiverval- \\ Grignon, France; Jérôme Enjalbert, UMR 320 Génétique Végétale, INRA, Ferme du Moulon, 91190 Gif sur Yvette, France; \\ Marc Delos, SRAl, Cité administrative, Bat E, bd Armand Duportal, 31074 Toulouse cedex, France; and Jacques Rouzet, SRAl, rue \\ Alco, BP 3056, 34034 Montpellier cedex France
}

\begin{abstract}
de Vallavieille-Pope, C., Ali, S., Leconte, M., Enjalbert, J., Delos, M., and Rouzet, J. 2012. Virulence dynamics and regional structuring of Puccinia striiformis f. sp. tritici in France between 1984 and 2009. Plant Dis. 96:131-140.

Understanding of long-term virulence dynamics of pathogen populations in response to host resistance gene deployment is of major importance for disease management and evolutionary biology. We monitored the virulence dynamics of Puccinia striiformis f. sp. tritici, the causal agent of wheat stripe rust, over 25 years in France. Virulence dynamics was explained by estimates of area associated with resistance genes carried by farmers' cultivars. The epidemics assessed through disease severity significantly correlated with the number of $P$. striiformis $\mathrm{f}$. sp. tritici isolates collected each year, used to describe virulence dynamics. In the south, the dominance of the Mediterranean pathotype 6E16 and the cultivation of a susceptible cultivar were associated with an epidemic from 1997 to 1999. In the north, five epidemics occurred due

to successive acquisition of virulence to the resistance genes $\operatorname{Yr} 7, \operatorname{Yr} 6$, $\operatorname{Yr} 9, \operatorname{Yr} 17$, and $\operatorname{Yr} 32$, either by acquisition of the virulence in the previous dominant pathotype or by incursion or selection of one or two new pathotypes. Frequency of pathotypes with $V r 7$ and $V r 6$ declined with the reduction in the cultivation of corresponding $Y r$ gene cultivars, whereas the virulence $\operatorname{Vr} 9$ persisted longer than the cultivation of $\operatorname{Yr} 9$ cultivars. Although the first pathotypes carrying $\operatorname{Vr} 9$ decreased, this virulence persisted in other pathotypes even in the absence of $Y r 9$ cultivars. At the regional level, $\operatorname{Yr} 9$ cultivars in the north caused a shift from high $\operatorname{Vr} 6$ frequency to high $\operatorname{Vr} 9$ frequency whereas, in the central region, where $\operatorname{Yr} 9$ cultivars were rare, $\operatorname{Vr} 6$ remained prevalent.
\end{abstract}

Stripe rust (yellow rust) of wheat (Triticum aestivum L.), caused by Puccinia striiformis f. sp. tritici Eriks., is a disease of worldwide economic importance $(2,23,30,50,52)$. The deployment of resistance genes has been suggested to be the most economical and environmentally friendly measure to control the disease $(2,22,48,50)$. At least 53 yellow rust resistance genes $(Y r)$ have been identified (42,53). These resistance genes are designated with $Y r$ and a suffix (i.e., $Y r 1, Y r 2, Y r 3$, and so on) according to the sequence of their genetic characterization (42), and the matching virulences to these resistance genes are designated as $V r 1, V r 2, V r 3$, and so on, respectively. These resistance genes are mostly race specific, fitting the well-described gene-for-gene theory $(14,15,26)$. Most of these genes are expressed at all growth stages of the plant but some are effective only at the adult-plant stage. Most of these resistance genes have been deployed in different cultivars, at different geographical scales (region, country, and continent), and for different periods of time, and, in general, have been associated with short-term stripe rust control $(8,33,52)$.

When resistance genes are deployed in popular cultivars on a large area, strong selective pressure occurs in the pathogen population $(33,35,41,52,56)$. Selection pressure caused by the deployment of resistance genes within host populations is particularly effective for biotrophic pathogens such as $P$. striiformis f. sp. tritici, because their entire life cycle depends on the availability of susceptible living host tissue. Thus, virulent pathotypes are rapidly selected,

Corresponding author: C. de Vallavieille-Pope,

E-mail: pope@grignon.inra.fr

Accepted for publication 13 July 2011.

http://dx.doi.org/10.1094/PDIS-02-11-0078

(C) 2012 The American Phytopathological Society leading to a loss of resistance-gene efficacy and, subsequently, to a reduction in the cultivation of cultivars carrying this sole source of resistance $(8,41)$. The overall pathogen population may then either become more complex through virulence accumulation in the same pathotype $(22,36,52)$ via strong direct or indirect (hitchhiking) selection (32), or remain quite stable, having the same mean number of virulences per pathotype (4), depending on the disease and the region studied. Despite considerable interest in understanding how host selection pressure and pathogen adaptive potential interact in the temporal dynamics of epidemics, few studies have described the changes in virulence frequency over a relatively long period of time and, hence, taken into account the temporal evolution of area allocated to the corresponding resistance genes.

In France, stripe rust most frequently occurred in the north, where devastating epidemics in the 1960s ('Joss Cambier', Yr11) led to greater emphasis on breeding for resistance to this disease (49). Since that time, a number of resistance genes have been deployed in wheat cultivars. The $P$. striiformis $\mathrm{f}$. sp. tritici population pathotype survey began in 1984 in order to monitor the evolution of virulence frequencies in the French $P$. striiformis f. sp. tritici population using a set of differential cultivars $(21,22)$. The northwestern European $P$. striiformis f. sp. tritici population, which included northern French $P$. striiformis f. sp. tritici populations, was described as being predominantly clonal $(25,29)$ and, therefore, most similar to that reported for the Australian (55) and northern American (12) P. striiformis f. sp. tritici populations, while Oriental and Asiatic populations appeared to have varying level of diversity $(1,24,40)$. Despite this clonal behavior, a succession of pathotypes has been detected in France across six major epidemics, due to stepwise mutations and acquisition of new virulences (25). The clonality of $P$. striiformis f. sp. tritici populations in France and the succession of a low number of pathotypes dominating the country provided a unique model to 
study the temporal dynamics of adaptation of $P$. striiformis $\mathrm{f}$. sp. tritici to resistance gene selective pressures.

Despite the long-distance migration capacity of $P$. striiformis $\mathrm{f}$. sp. tritici (11), a clear divergence has been reported in the northern and southern French $P$. striiformis f. sp. tritici populations (25), partly due to temperature adaptation (39) and, apparently, to resistance gene deployment. This highlights the role of host genetic composition at the regional level. To better understand the role of host gene deployment on regional population structure, we used the case of $\operatorname{Yr} 6$ and $\operatorname{Yr} 9$ cultivation in two regions. We assessed whether the cultivation of the Yr9-based 'Slejpner' in northern France and of the Yr6-based 'Récital' in both the northern and central regions (GNIS, http://www.gnis.fr/) (22) might influence the $P$. striiformis f. sp. tritici population structure at the regional level.

The first objective of this study was to determine whether the pathotype dynamics of $P$. striiformis f. sp. tritici in France may be explained by changes in the deployment of resistance genes at the national level, with particular emphasis on the subsequent evolution of the corresponding virulences over a long period of time. The second objective was to see whether different host population structures at the regional level made it possible to study their effect on the pathogen population structure. We used the annual pathotype and epidemic severity surveys conducted at the national level to find answers to these questions.

\section{Materials and Methods}

Temporal fluctuations in the severity of stripe rust epidemics. Annual surveys of the severity of stripe rust epidemics were carried out by the Plant Protection Service, Ministry of Agriculture, Paris. These estimates were used as indicators of epidemic intensity. Detailed observations on disease severity were available from 1975 in all production regions within France and had been undertaken by a specialized network concerning cereal diseases. Disease severity was assessed by visual scoring in farmers' fields throughout France. For the present study, the scores averaged across all sites from northern and southern France each year were represented on a scale from 0 to 3 , where $0=$ no disease; $0.5=$ rare epidemic cases observed; 1 = limited disease severity, either low severity across a large area or high severity limited to a very small area; $2=$ severe disease severity over a large area with maximum severity (i.e., 70\%); and $3=$ high disease severity with a larger area severely infected (disease severity $>70 \%$ ). The disease severity score presented herein was the median based on the distribution of severity scores per year for representative regions in the north and south of France. Each region comprised about 300 farmers' fields and 10 different cultivars. The disease evaluation in each reference field in an area not treated with fungicides was based on weekly visual observations of diseased leaf area on susceptible or highly susceptible cultivars.

Survey of $\boldsymbol{P}$. striiformis $\mathbf{f}$. sp. tritici pathotypes. The frequency of $P$. striiformis f. sp. tritici pathotypes was monitored throughout France in farmers' fields and noninoculated breeding nurseries beginning in 1984. For the present study, information was obtained from a range of institutes, including Service de la Protection des Végétaux, Ministry of Agriculture, Paris; Arvalis-Institut du Végétal, Paris; Chambers of Agriculture; agrochemical companies; and wheat breeders. Randomly selected samples of diseased wheat leaves were collected from fields that were not inoculated. The leaves were wrapped in glycine bags or paper envelopes and sent to the INRA laboratory in Versailles-Grignon. An isolate of a single sporulating lesion was obtained from each sample and then used for subsequent pathotyping.

The $P$. striiformis f. sp. tritici survey performed in northern France during the period from 1987 to 1992 was used to assess the regional structure of the $P$. striiformis $\mathrm{f}$. sp. tritici population in relation to resistance gene distribution of cultivars in farmers' fields. In one region of northern France that included the cities of Lille $\left(50^{\circ} 38^{\prime} 14^{\prime \prime} \mathrm{N}, 3^{\circ} 03^{\prime} 48^{\prime \prime} \mathrm{E}\right)$ and Amiens $\left(49^{\circ} 54^{\prime} 0^{\prime \prime} \mathrm{N}, 2^{\circ} 18^{\prime} 0^{\prime \prime}\right.$ E), Slejpner, which carried the resistance gene $\operatorname{Yr} 9$ (7), was widely cultivated at that time; whereas, in one region of central France, including Paris $\left(48^{\circ} 51^{\prime} 24^{\prime \prime} \mathrm{N}, 2^{\circ} 21^{\prime} 07^{\prime \prime} \mathrm{E}\right)$ and Orléans $\left(47^{\circ} 54^{\prime} 09^{\prime \prime}\right.$ $\mathrm{N}, 1^{\circ} 54^{\prime} 32^{\prime \prime} \mathrm{E}$ ), Slejpner was not grown and Récital (carrying Yr6; 22) was predominant. 'Thésée' $(Y r 2)$ was grown in both regions and was susceptible to all prevalent pathotypes (either avirulent or virulent to $\operatorname{Yr} 6$ and $\operatorname{Yr} 9$ ), because all pathotypes found during this period carried $V r 2$ (22). The frequencies of $V r 9$ and $V r 6$ were compared between the two regions to assess the regional structure of the $P$. striiformis $\mathrm{f}$. sp. tritici population relative to the distribution of resistance genes.

Spore purification and multiplication. The $P$. striiformis $\mathrm{f} . \mathrm{sp}$. tritici samples collected from the field were purified and multiplied in a greenhouse for further pathotyping. Five wheat seeds per pot were planted in square pots ( 7 by 7 by $8 \mathrm{~cm}$ ) filled with standard peat soil. In order to enhance spore production, the plants were treated with $15 \mathrm{ml}$ of maleic hydrazide solution $(0.25 \mathrm{~g} /$ liter $)$ per pot when seedlings were $1 \mathrm{~cm}$ high, 4 to 5 days after sowing. All isolates were single lesion and urediniospores were produced through inoculation on seedlings at the two-leaf stage of the susceptible wheat 'Michigan Amber' or 'Victo'. The latter cultivar is highly susceptible to the northwestern European stripe rust population and resistant to most of the leaf (brown) rust pathotypes (23). Starting in the early 2000s, the plants were kept in a greenhouse under continuous light for $6 \mathrm{~h}$ before inoculation to increase infection efficiency, with a light intensity of $300 \mu \mathrm{mol}$ quanta $\mathrm{m}^{-2} \mathrm{~s}^{-1}$ (19). Inoculated plants were kept in a dark dew chamber at $8^{\circ} \mathrm{C}$ for $24 \mathrm{~h}$ and then placed in a greenhouse where the temperature was maintained between $14^{\circ} \mathrm{C}$ at night and a maximum of $20^{\circ} \mathrm{C}$ during day time. The daylight period was extended to $16 \mathrm{~h}$ through the use of sodium vapor lamps (with a light intensity of $300 \mu \mathrm{mol}$ quanta $\mathrm{m}^{-2} \mathrm{~s}^{-1}$ ). Plastic cylinders or cellophane bags were placed over each pot to prevent any cross-contamination. Plants bearing a single lesion on a leaf were isolated in a cellophane bag to produce single-lesion isolates, and the spores collected from this single lesion were multiplied for further use. Seedlings were inoculated with urediniospores mixed with talc. Urediniospores from plants inoculated 15 to 21 days earlier were harvested using a cyclone spore collector. These spores were placed in a desiccator $(40 \%$ relative humidity) for 4 days at $5^{\circ} \mathrm{C}$ and then stored in liquid nitrogen (20). After removal from storage, the urediniospores were heat shocked $\left(40^{\circ} \mathrm{C}\right.$ for $\left.10 \mathrm{~min}\right)$ before inoculation and used for either spore multiplication or virulence profile tests.

Characterization of virulence profiles of $P$. striiformis $\mathbf{f}$. $\mathbf{s p}$. tritici. The virulences of $P$. striiformis $\mathrm{f}$. sp. tritici isolates were determined using world and European sets of 15 differential lines $(22,34)$ plus additional varieties: 'Chinese 166' ( $Y r 1)$, 'Kalyonsona' (Yr2), 'Heines VII' (Yr2+), 'Vilmorin 23' (Yr3), 'Nord Desprez' (Yr3+), 'Hybrid 46' (Yr4), T. spelta album (Yr5), 'Austerlitz' (Yr6), 'Heines Kolben' (Yr6+), 'Heines Peko' (Yr6 and Yr2), 'Lee' (Yr7), 'Reichersberg 42' (Yr7+), 'Compair' (Yr8+), 'Federation 4×/Kavkaz' ( $Y r 9)$, 'Clement' (Yr9+), 'Moro' (Yr10), 'VPM1' (Yr17), line TP981 (Yr25), Avocet isoline (Yr27), 'Carstens V' (Yr32), 'Strubes Dickkopf' ( $Y r S d)$, 'Spaldings Prolific' $(Y r S p)$, and 'Suwon92/Omar' (YrSu) (http://www.ars.usda.gov/SP2UserFiles/ ad_hoc/36400500Resistancegenes/Yrgene.xls). Each differential line carried at least one race-specific resistance gene $(Y r)$ expressed at the seedling stage. The "+" sign after the name of the $Y r$ gene indicated additional unknown resistance. During each test, Michigan Amber or Victo was included as a susceptible control $(22,23)$. Each test included six plants for each isolate-wheat genotype combination and was conducted twice. All the conditions of plant growth and inoculum production were as described above. The seedlings were inoculated 8 to 10 days after sowing, when the first leaf was fully expanded and the second leaf emerging. Seedlings were inoculated using $4 \mathrm{mg}$ of spores suspended in 650 $\mu \mathrm{l}$ of Soltrol 170 mineral oil (Chevron-Phillips Chemical Co., Houston). After $15 \mathrm{~min}$ for oil evaporation, inoculated seedlings were kept in a dark dew chamber for $24 \mathrm{~h}$ at $8^{\circ} \mathrm{C}$ before being placed in a greenhouse (as described above) to promote disease development. Seedling responses were assessed 17 to 19 days after 
inoculation, using a qualitative infection-type scale of 0 to 9 defined by the presence of necroses and chloroses and the intensity of sporulation (43) (http://public.wsu.edu/ wheaties/rustpic.html). Compatible reactions (host susceptibility and pathogen virulence) were defined as infection types 7 to 9 . Infection types 0 to 4 were defined as incompatible reactions (host resistance and pathogen avirulence) and infection types 5 to 6 were considered to be intermediate reactions.

The virulence phenotypes of the isolates were used according to the pathotyping nomenclature (34) and their complete virulence profile. The pathotype code is binary; the first number corresponded to the avirulent or virulent infection types on the world differential set and the second number described avirulent or virulent infection types on the European differential set. The final number indicated avirulent or virulent infection types on the additional differential lines for $Y r 17$ and $Y r 27$.

Postulation of stripe rust resistance genes. The geographical distribution of cultivars was provided by the Office National Interprofessionnel des Grandes Cultures, Paris (47) and ArvalisInstitut du Végétal, Paris. Resistance genes were determined at the seedling stage using a set of 12 French pathotypes with complementary virulence patterns: 2 southern $P$. striiformis f. sp. tritici pathotypes, 6E16 ( $V r 2,6,7$, and 8) and 6E16V27 ( $V r 2,6,7,8,9$, 25,27 , and $S d$ ); and 10 northern $P$. striiformis f. sp. tritici pathotypes: 237E141V17 ( $V r 1,2,3,4,6,9,17, S d$, and $S u)$, 169E136V17 (Vrl, 2, 3, 9, 17, and $S d)$, 40E8 (Vr3 and $S d)$, 43E138 $(V r 1,2,3,7$, and $S d), 106 \mathrm{E} 139(V r 2,3,4,7, S d$, and $S u), 109 \mathrm{E} 141$ ( $V r 1,2,3,4,6, S d$, and $S u$ ), 232E137 (Vr2, 3, 4, 9, Sd, and $S u$ ), 233E169V17 ( $V r 1,2,3,4,9,17,32, S d$, and $S u$ ), 237E141 (Vrl, 2, 3, 4, 6, 9, Sd, and $S u$ ), and 239E141V17 ( $V r l, 2,3,4,6,7,9,17$, $\mathrm{Sd}$, and $\mathrm{Su}$ ) (22). The cultivars grown during the study period were tested at the seedling stage, with the same conditions as described above for pathotype determination (22).

\section{Results}

Prevalence and severity of stripe rust epidemics. In total, 1,574 isolates were collected over the 25 -year period: 1,362 isolates from the north and 212 from the south (Fig. 1). The geographical distribution of the number of isolates sampled per department was six times higher in the north than in the south. Northcentral France (departments of Calvados, Essonne, Eure, Eure et Loir, Ille et Vilaine, Loir et Cher, Nord, Oise, Pas de Calais, Seine et Marne, Seine Maritime, Somme, and Yvelines) had the highest number of isolates collected in the north, ranging from 25 to 206 isolates per department. In southwestern and eastern France, where the area of wheat cultivation was lower (www.gnis.fr), fewer isolates were received. The analyses of pathotypes and disease severity considered the north and south of France separately. The maximum number of isolates received $(n=200)$ was in 1999 , with 180 of them originating from northern regions with a disease severity score of 2, corresponding to the 1999 to 2002 P. striiformis $\mathrm{f}$. sp. tritici epidemics (Table 1; Fig. 2A). The number of isolates received in 1989 (121 isolates) corresponded to the 1988 to $1991 P$. striiformis f. sp. tritici epidemics. The number of isolates in 2008 (124 isolates) that corresponded to the 2007 to 2009 P. striiformis f. sp. tritici epidemics was also high. A moderate epidemic observed in 1994 (57 isolates) corresponded to the 1993 to $1995 P$. striiformis f. sp. tritici epidemics. For southern France, the maximum number of isolates $(n=72)$ was collected in 1997 and corresponded to the 1996 to 2001 P. striiformis f. sp. tritici epidemics that were due to the cultivation of Victo. Those epidemic periods corresponded to disease severity scores higher than 2 on the 0-to-3 scale (Fig. 2A and B). There were four periods with no epidemics: in 1986, 1992, 1996, and 2004 to 2006. For these years, the number of isolates received was below 10 isolates per year and the disease severity score was lower than 0.5 .

The sources of isolates were the surveys conducted by the Plant Protection Service, and it was hypothesized that the number of isolates collected each year was indicative of epidemic severity of that year. The severity of stripe rust epidemics and the number of isolates received each year were found to be strongly correlated (for the north: $R^{2}=0.661$ and $P<0.001$, Fig. $2 \mathrm{~A}$; for the south: $R^{2}$ $=0.608$ and $P<0.001$, Fig. 2B), showing that the number of $P$. striiformis $\mathrm{f}$. sp. tritici isolates received annually varied in line with epidemic severity (Fig. 2A and B). Because we were interested in the relative frequency of pathotypes and virulences, henceforth, epidemic status was described using the number of isolates received per year rather than disease severity.

The virulence frequency over the 25 -year period in the north revealed a succession of five epidemics, due to the sequential selection of the virulences $\operatorname{Vr} 7, \operatorname{Vr} 6, \operatorname{Vr} 9, \operatorname{Vr} 17$, and $\operatorname{Vr} 32$ (Fig. 3A). The $\operatorname{Vr} 7$ frequency was high in 1984 and then declined. The $\operatorname{Vr} 6$ frequency fluctuated three times from high to low and then to high again. The $V r 9$ and $V r l 7$ virulences remained fixed in the population after their selection. Finally, the $V r 32$ frequency was only high at the end of the period. In the south, there was a single large epidemic, which was caused by a pathotype combining $\operatorname{Vr} 7$ and $V r 6$ (Fig. 3B). $\operatorname{Vr} 9$ and $\operatorname{Vr} 17$ were detected in 2000 in the south, corresponding to some pathotypes characteristic of the north.

In total, 23 pathotypes were detected from the 1,574 P. striiformis $\mathrm{f}$. $\mathrm{sp}$. tritici isolates collected during the study period. In all, 20 pathotypes were identified in northern France and 14 in southern France (Table 1). In the north, a succession of pathotypes was detected during the 25 -year period. During the epidemic in 1984, pathotype 43E138 containing $V r 7$ virulence was dominant but decreased thereafter, coinciding with the diminishing production area of Talent ( $Y r 7$ ) (Fig. 4A). The epidemics of 1987 to 1989 were due to two new pathotypes (45E140 and 109E141) with Vr6 virulence, collected mainly from Yr6-based Récital and Austerlitz (Fig. 4B). The next most frequent pathotype was 232E137, containing $\operatorname{Vr} 9$ virulence, which was detected in 1986 and became prevalent between 1990 and 1994 before declining. The prevalence of 232E137 was mainly due to the cultivation of Slejpner (Yr9). In 1989, another pathotype (237E141) appeared carrying $V r 6$ in addition to $V r 9$. This was concomitant with the cultivation of 'Equinox' and 'Madrigal', containing both $\operatorname{Yr} 6$ and Yr9. In 1998, the two major newly detected pathotypes (233E137V17 and 169E136V17) contained both the $\operatorname{Vr} 9$ and $\operatorname{Vr} 17$
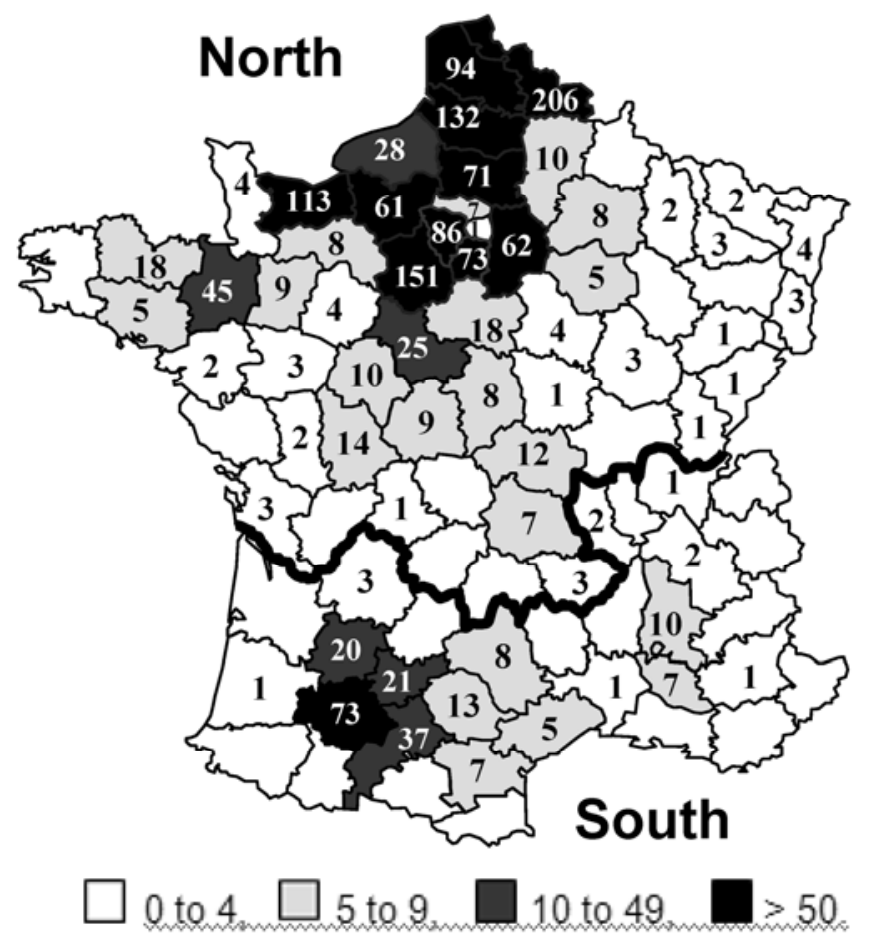

Fig. 1. Distribution of the 1,574 Puccinia striiformis f. sp. tritici isolates collected between 1984 and 2009 in 93 French departments. Range of numbers of isolates per department: white areas, 0 to 4; light gray areas, 5 to 9; dark gray areas, 10 to 49 , and black areas, $>50$. 
virulences. The $\operatorname{Vr} 9$ virulence was already widespread and the $\operatorname{Vr} 17$ virulence was newly detected. The pathotypes 233E137V17 and 169E136V17 were found from 1998 to 2004. In 1999, a new pathotype (237E141V17) possessing $\operatorname{Vr} 9$, $\operatorname{Vr} 6$, and $\operatorname{Vr} 17$ was identified, associated with the cultivation of 'Ornicar' and 'Cardos', containing both Yr6 and Yr17. This pathotype frequency declined after 2003 and increased again in 2009.

Another pathotype (233E169V17), containing $\operatorname{Vr} 9$, Vr17, and $\operatorname{Vr} 32$, was detected in 2002 and became frequent during the epidemics of 2007 to 2009 , while the pathotype 104E41, containing $\operatorname{Vr} 32$ without $\operatorname{Vr} 9$ and $\operatorname{Vr} 17$, was detected in 2008 and 2009. The Yr32 gene was present mainly in 'Toisondor', 'Aldric', and 'Alixan'. Some other minor pathotypes were also detected during this 25-year period but at a very low frequency (Table 1).
By contrast, the southern French $P$. striiformis f. sp. tritici population was clearly dominated by the pathotype 6E16 (150 isolates), with the remaining pathotypes, including four specific to the south, being encountered much less frequently (Table 1). The highest number of $6 \mathrm{E} 16$ isolates sampled (53 isolates out of the total of 150 such isolates collected during the 25 -year period) was observed in 1997. The earlier 1986 epidemic, due to infection of spring wheat 'Prinqual' in the Rhône-Alpes region (south of France), was also caused by the pathotype 6E16.

Moreover, despite the marked divergence between northern and southern $P$. striiformis f. sp. tritici populations, some pathotypes from the north were found at very low frequencies in the south during the years of severe epidemics (Table 1). Similarly, the dominant pathotype in southern France (6E16) was found at a very

Table 1. Annual frequency and virulence profile of Puccinia striiformis f. sp. tritici pathotypes detected in northern and southern France between 1984 and 2009

\begin{tabular}{|c|c|c|c|c|c|c|c|c|c|c|c|c|c|c|c|c|c|c|c|c|c|c|c|c|c|c|c|}
\hline \multirow[b]{2}{*}{ Pathotype $^{b}$} & \multicolumn{26}{|c|}{ Year $^{a}$} & \multirow[b]{2}{*}{ Virulence $^{c}$} \\
\hline & 84 & 85 & 86 & 87 & 88 & 89 & 90 & 91 & 92 & 93 & 94 & 95 & 96 & 97 & 98 & 99 & 00 & 01 & 02 & 03 & 04 & 05 & 06 & 07 & 08 & 09 & \\
\hline \multicolumn{28}{|l|}{ North } \\
\hline 43E138 & 83 & 90 & + & + & 7 & 2 & - & - & - & - & - & - & - & - & - & - & - & - & - & - & - & - & - & - & - & - & $1,2,3,7,25, \mathrm{Sd}$ \\
\hline 171E138 & 17 & - & - & - & - & - & - & - & - & - & - & - & - & - & - & - & - & - & - & - & - & - & - & - & - & - & $1,2,3,7,9,25, \mathrm{Sd}$ \\
\hline $41 \mathrm{E} 136$ & - & 10 & - & 17 & 6 & 1 & - & - & - & - & - & - & - & - & - & - & - & - & - & - & - & - & - & - & - & - & $1,2,3,25, \mathrm{Sd}$ \\
\hline 232E137 & - & - & + & - & 3 & 21 & 44 & 52 & + & 44 & 46 & 38 & + & - & - & - & - & - & - & - & - & - & - & - & - & - & $2,3,4,9,25, \mathrm{Sd}, \mathrm{Su}$ \\
\hline 109E141 & - & - & - & 6 & 15 & 14 & 13 & 3 & - & - & 2 & 3 & - & + & 3 & - & - & 2 & - & - & - & - & - & - & - & - & $1,2,3,4,6,25, \mathrm{Sd}, \mathrm{Su}$ \\
\hline $169 \mathrm{E} 136$ & - & - & - & 11 & - & 1 & 3 & 6 & + & 38 & 26 & 13 & + & - & - & - & - & - & - & - & - & - & - & - & - & - & $1,2,3,9,25, \mathrm{Sd}$ \\
\hline $45 \mathrm{E} 140$ & - & - & - & 56 & 67 & 58 & 35 & 6 & - & 3 & - & 5 & + & - & - & - & 1 & 1 & - & - & - & - & - & - & - & - & $1,2,3,6,25, \mathrm{Sd}$ \\
\hline 233E137 & - & - & - & 6 & - & - & - & - & - & - & - & - & - & - & - & - & - & - & - & - & - & - & - & - & - & - & $1,2,3,4,9,25, \mathrm{Sd}, \mathrm{Su}$ \\
\hline $235 \mathrm{E} 139$ & - & - & - & - & 3 & - & - & - & - & - & - & - & - & - & - & - & - & - & - & - & - & - & - & - & - & - & $1,2,3,4,7,9,25, \mathrm{Sd}, \mathrm{Su}$ \\
\hline 237E141 & - & - & - & - & - & 3 & 3 & 30 & + & 16 & 26 & 41 & - & + & - & - & - & - & 1 & - & + & - & - & - & 2 & - & $1,2,3,4,6,9,25, \mathrm{Sd}, \mathrm{Su}$ \\
\hline 106E139 & - & - & - & - & - & - & 2 & - & - & - & - & - & - & + & - & - & - & - & - & - & + & - & - & - & - & - & $2,3,4,7,25, \mathrm{Sd}, \mathrm{Su}$ \\
\hline 169E136V17 & - & - & - & - & - & - & - & - & - & - & - & - & - & + & 26 & 5 & 2 & 6 & 2 & 21 & - & - & - & 3 & - & - & $1,2,3,9,17, \mathrm{Sd}$ \\
\hline 233E137V17 & - & - & - & - & - & - & - & - & - & - & - & - & - & + & 68 & 89 & 91 & 75 & 41 & 43 & + & - & - & 1 & - & - & $1,2,3,4,9,17,25, \mathrm{Sd}, \mathrm{Su}$ \\
\hline 237E141V17 & - & - & - & - & - & - & - & - & - & - & - & - & - & - & - & 1 & 1 & 11 & 48 & 29 & - & - & - & 1 & - & 42 & $1,2,3,4,6,9,17,25, \mathrm{Sd}, \mathrm{Su}$ \\
\hline 173E140V17 & - & - & - & - & - & - & - & - & - & - & - & - & - & - & - & - & - & 1 & 2 & - & + & - & - & - & - & - & $1,2,3,6,9,17,25, \mathrm{Sd}$ \\
\hline 239E143V17 & - & - & - & - & - & - & - & - & - & - & - & - & - & - & - & - & - & 1 & - & - & - & - & - & - & - & - & $1,2,3,4,6,7,9,17,25, \mathrm{Sd}, \mathrm{Su}$ \\
\hline 233E169V17 & - & - & - & - & - & - & - & - & - & - & - & - & - & - & - & - & - & - & 5 & 7 & - & - & - & 96 & 77 & 31 & $1,2,3,4,9,17,32,25, \mathrm{Sd}, \mathrm{Su}$ \\
\hline $104 \mathrm{E} 41$ & - & - & - & - & - & - & - & - & - & - & - & - & - & - & - & - & - & - & - & - & - & - & - & - & 21 & 27 & $3,4,6,32,25, \mathrm{Sd}, \mathrm{Su}$ \\
\hline $6 \mathrm{E} 16$ & - & - & + & - & - & - & - & 3 & - & - & - & - & - & - & 3 & 4 & 4 & 4 & 2 & - & - & - & - & - & - & - & $2,6,7,8$ \\
\hline $40 \mathrm{E} 8$ & - & - & - & - & - & - & - & - & - & - & - & - & - & - & - & - & - & - & - & - & - & - & - & - & - & - & $2,3,25, \mathrm{Sd}$ \\
\hline OE 0 & - & - & - & - & - & - & - & - & - & - & - & - & - & - & - & - & - & - & - & - & - & - & - & - & - & - & - \\
\hline $32 \mathrm{E} 0$ & - & - & - & - & - & - & - & - & - & - & - & - & - & - & - & 1 & - & - & - & - & - & - & - & - & - & - & $25, \mathrm{Sd}$ \\
\hline $6 \mathrm{E} 16 \mathrm{~V} 27$ & - & - & - & - & - & - & - & - & - & - & - & - & - & - & - & - & - & - & - & - & - & - & - & - & - & - & $2,6,7,8,9,25,27,(\mathrm{Sd})$ \\
\hline Isolate no. & 12 & 10 & 4 & 18 & 72 & 121 & 63 & 33 & 4 & 32 & 57 & 39 & 8 & 8 & 34 & 180 & 90 & 108 & 105 & 14 & 7 & 0 & 0 & 115 & 124 & 104 & \\
\hline \multicolumn{28}{|l|}{ South } \\
\hline 43E138 & - & - & - & - & - & - & - & - & - & - & - & - & - & - & - & - & - & - & - & - & - & - & - & - & - & - & $1,2,3,7,25, \mathrm{Sd}$ \\
\hline 171E138 & - & - & - & - & - & - & - & - & - & - & - & - & - & - & - & - & - & - & - & - & - & - & - & - & - & - & $1,2,3,7,9,25, \mathrm{Sd}$ \\
\hline $41 \mathrm{E} 136$ & - & - & - & + & - & - & - & - & - & - & - & - & - & - & - & - & - & - & - & - & - & - & - & - & - & - & $1,2,3,25, \mathrm{Sd}$ \\
\hline $232 \mathrm{E} 137$ & - & + & - & - & - & - & - & - & - & - & + & - & - & 1 & 3 & - & 7 & - & - & + & - & - & - & - & - & - & $2,3,4,9,25, \mathrm{Sd}, \mathrm{Su}$ \\
\hline 109E141 & - & - & - & - & - & - & - & - & - & - & - & - & - & 6 & - & - & - & - & - & - & - & - & - & - & - & - & $1,2,3,4,6,25, \mathrm{Sd}, \mathrm{Su}$ \\
\hline 169E136 & - & - & - & - & - & - & - & - & - & - & - & - & - & - & 3 & - & - & - & - & + & - & - & - & - & - & - & $1,2,3,9,25, \mathrm{Sd}$ \\
\hline $45 \mathrm{E} 140$ & - & - & - & - & - & - & + & - & - & - & - & - & - & 4 & 3 & - & - & - & - & - & - & - & - & - & - & - & $1,2,3,6,25, \mathrm{Sd}$ \\
\hline 233E137 & - & - & - & - & - & - & - & - & - & - & - & - & - & - & - & - & - & - & - & - & - & - & - & - & - & - & $1,2,3,4,9,25, \mathrm{Sd}, \mathrm{Su}$ \\
\hline $235 \mathrm{E} 139$ & - & - & - & - & - & - & - & - & - & - & - & - & - & - & - & - & - & - & - & - & - & - & - & - & - & - & $1,2,3,4,7,9,25, \mathrm{Sd}, \mathrm{Su}$ \\
\hline 237E141 & - & - & - & - & - & - & - & - & - & - & - & - & - & - & - & - & - & - & - & - & - & - & - & - & - & - & $1,2,3,4,6,9,25, \mathrm{Sd}, \mathrm{Su}$ \\
\hline $106 \mathrm{E} 139$ & - & - & - & - & - & - & - & - & - & - & - & - & - & - & - & - & - & - & - & - & - & - & - & - & - & - & $2,3,4,7,25, \mathrm{Sd}, \mathrm{Su}$ \\
\hline 169E136V17 & - & - & - & - & - & - & - & - & - & - & - & - & - & - & 5 & - & - & 3 & - & - & - & - & - & - & - & - & $1,2,3,9,17, \mathrm{Sd}$ \\
\hline 233E137V17 & - & - & - & - & - & - & - & - & - & - & - & - & - & - & - & - & 50 & - & - & + & - & - & - & - & - & - & $1,2,3,4,9,17,25, \mathrm{Sd}, \mathrm{Su}$ \\
\hline 237E141V17 & - & - & - & - & - & - & - & - & - & - & - & - & - & - & - & - & - & - & - & - & - & - & - & - & - & - & $1,2,3,4,6,9,17,25, \mathrm{Sd}, \mathrm{Su}$ \\
\hline 173E140V17 & - & - & - & - & - & - & - & - & - & - & - & - & - & - & - & - & - & - & - & - & - & - & - & - & - & - & $1,2,3,6,9,17,25, \mathrm{Sd}$ \\
\hline 239E143V17 & - & - & - & - & - & - & - & - & - & - & - & - & - & - & - & - & - & - & - & - & - & - & - & - & - & - & $1,2,3,4,6,7,9,17,25, \mathrm{Sd}, \mathrm{Su}$ \\
\hline 233E169V17 & - & - & - & - & - & - & - & - & - & - & - & - & - & - & - & - & - & - & - & - & - & - & - & - & + & - & $1,2,3,4,9,17,32,25, \mathrm{Sd}, \mathrm{Su}$ \\
\hline 104E41 & - & - & - & - & - & - & - & - & - & - & - & - & - & - & - & - & - & - & - & - & - & - & - & - & + & + & $3,4,6,32,25, \mathrm{Sd}, \mathrm{Su}$ \\
\hline $6 \mathrm{E} 16$ & - & - & + & - & - & - & - & - & - & - & - & - & + & 74 & 67 & 100 & 43 & 97 & + & - & - & - & - & - & - & - & $2,6,7,8$ \\
\hline $40 \mathrm{E} 8$ & - & - & - & - & - & - & - & - & - & - & - & - & + & 8 & 3 & - & - & - & - & - & - & - & - & - & - & - & $2,3,25, \mathrm{Sd}$ \\
\hline OE0 & - & - & - & - & - & - & - & - & - & - & - & - & - & 4 & - & - & - & - & - & - & - & - & - & - & - & - & - \\
\hline $32 \mathrm{E} 0$ & - & - & - & - & - & - & - & - & - & - & - & - & - & 3 & 18 & - & - & - & - & - & - & - & - & - & - & - & $25, \mathrm{Sd}$ \\
\hline 6E16V27 & - & - & - & - & - & - & - & - & - & - & - & - & - & - & - & - & - & - & - & - & + & - & - & - & - & - & $2,6,7,8,9,25,27,(\mathrm{Sd})$ \\
\hline Isolate no. & 0 & 1 & 6 & 2 & 0 & 0 & 1 & 0 & 0 & 0 & 1 & 0 & 9 & 72 & 39 & 20 & 14 & 33 & 1 & 3 & 4 & 0 & 0 & 0 & 5 & 1 & \\
\hline
\end{tabular}

a Symbols: + indicates that the pathotype was present but the frequency was not calculated because the number of isolates sampled that year was $<10$ and indicates that the pathotype was not detected.

${ }^{\mathrm{b}}$ Pathotypes were coded according to Johnson et al. (34). The virulences and avirulences tested were $\operatorname{Vrl}, 2,3,4,6,7,8,9,10,17,25,27,32, \mathrm{Sd}, \mathrm{Sp}, \mathrm{Su}$.

' Virulence profile. Factors $S d, S p$, and $S u$ referred to the resistance genes of the 'Strubes Dickkopf', 'Spalding Prolific'; and 'Suwon92' × 'Omar' cultivars, respectively. Sd infection types 5 to 6 were considered as intermediate reactions and were shown in parentheses. 
low frequency in the north (Alsace and Pas de Calais regions) on Victo, which was rarely grown in the north. Interestingly, each new pathotype was detected following epidemic-free years, as in the case of $\operatorname{Vr} 6$ (after the epidemic-free year of 1986), $\operatorname{Vrl} 7$ (after the epidemic-free years 1996 to 1997), and Vr32 (after the epidemicfree years 2005 to 2006).

Virulence dynamics versus resistance gene distribution. The dynamics of $P$. striiformis $\mathrm{f}$. sp. tritici virulence factors during the past 25 years have been strongly influenced by the relative distribution of resistance genes (Fig. 4). At the beginning of each epidemic, two to three new pathotypes have been detected carrying virulences that correlated with recent and widespread resistance genes, one of them subsequently becoming dominant. The frequency of this prevailing pathotype remained high for a few years and then declined, mainly in response to a reduction in the matching $Y r$ gene (as in the cases of $V r 7$ and $V r 6$; Fig. 4A and B). However, the virulence itself persisted for even longer in other pathotypes, even after the disappearance of the $Y r$ genes (as in the case of $V r 9$; Fig. 4C) or reappeared in some new pathotypes with additional virulences to the newly deployed resistance genes associated with the target resistance gene (as in the case of $\operatorname{Vr} 17$; Fig. 4D). In the case of Vr32, the corresponding resistance gene Yr32 was present up to the end of the study in the grown cultivars, and the Vr32 was selected (Fig. 4E).

The presence of $V r 7$ in $P$. striiformis f. sp. tritici isolates collected at the beginning of the study period was correlated with the relative distribution of a $Y r 7$-based cultivar ('Talent') and, indeed, its frequency declined during subsequent years as the cultivation of Talent decreased (Fig. 4A). The 1988 epidemic was more severe. Samples from seven regions (Nord, Picardie, Pays de la Loire, Ile de France, Bourgogne, Rhône-Alpes, and Bretagne) showed that the epidemic was caused by the $45 \mathrm{E} 140$ pathotype first identified in 1987 (Fig. 4B). This pathotype possessed the virulence that matched $\mathrm{Yr} 6$, a resistance gene carried by the widely

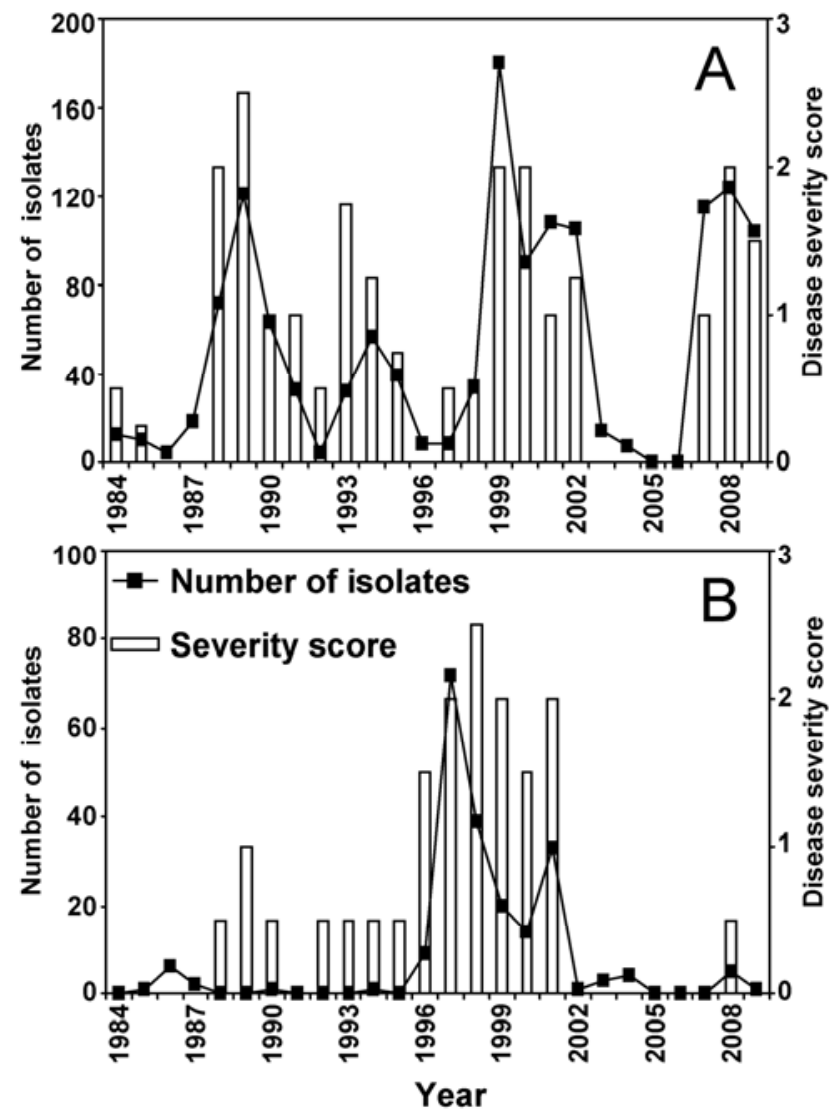

Fig. 2. Number of Puccinia striiformis f. sp. tritici isolates collected (black squares) over 25 years in $\mathbf{A}$, northern and $\mathbf{B}$, southern France. Disease severity score $(0$ to 3 ) is shown on a secondary axis. cultivated Récital and Austerlitz. Interestingly, Vr6 first appeared when Récital was at the seed multiplication stage in nurseries, before its commercial cultivation. The frequency of the two pathotypes (45E140 and 109E141) declined gradually as the cultivation of $Y r 6$-based cultivars decreased through 1992.

A pathotype analysis of the epidemics between 1990 and 1995 showed that the appearance of new pathotypes carrying $\operatorname{Vr} 9$ was strongly correlated with the increase of cultivation of $\mathrm{Yr} 9$-based cultivars (mainly Slejpner) during this period. After 1996, the $\operatorname{Vr} 9$ containing pathotypes initially detected declined significantly, although the presence of $\operatorname{Vr} 9$ remained constant in the population and was still being observed in other pathotypes during the post1996 epidemics (Fig. 4C). The epidemics between 1998 and 2002 were caused by pathotypes containing $\operatorname{Vr} 17$ and $\operatorname{Vr} 9$ and some $\operatorname{Vr} 6$, not found in French pathotypes before 1997. The distribution of Yrl7 cultivars had been limited in France before reaching $10 \%$ of grown wheat area in 1998 and 12\% in 1999 (8). Thus, the appearance of this virulence also corresponded with an increase in the production area of corresponding Yr17-carrying cultivars, mainly 'Audace', at the initiation of the epidemics (Fig. 4D). Although the initially detected $\operatorname{Vr} 17$-containing pathotypes decreased in frequency, some new pathotypes containing Vrl7 were identified during 2008 and 2009. Vr17 was associated with virulence Vr32, which overcomes the resistance gene $\operatorname{Yr} 32$, present in Toisondor, cultivated in France since 2004 (Fig. 4E).

Regional structure of $\boldsymbol{P}$. striiformis f. sp. tritici pathotypes. The relative production area planted with Récital (containing Yro), Slejpner (containing $\operatorname{Yr} 9$ ), and Thésée (susceptible, containing neither $Y r 6$ nor $Y r 9$ ) varied in two regions of northern and central France during the period 1987 to 1992 (Fig. 5). The relative area planted with Slejpner $(\operatorname{Yr} 9)$ was high in the north whereas it was rarely cultivated in the central region. Récital, on the other hand, was grown in both regions and was more widely cultivated in the central region than in the northern region. The frequency of iso-

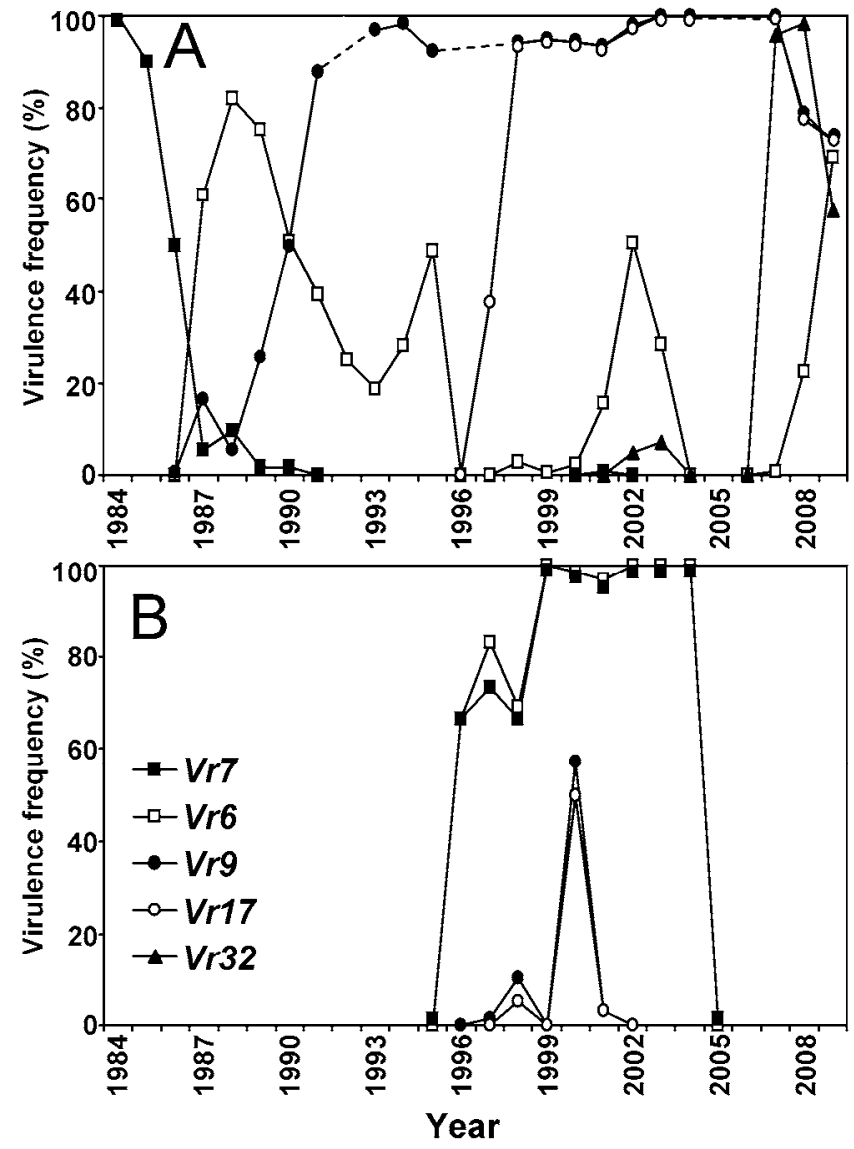

Fig. 3. Virulence $(V r)$ frequencies of Puccinia striiformis $\mathrm{f}$. $\mathrm{sp}$. tritici isolates collected each year between 1984 and 2009 in A, northern and B, southern France. 
lates with $\operatorname{Vr} 6$ or $\operatorname{Vr} 9$ detected on these three cultivars varied in the two regions during the period. Vr6 was detected in both regions from 1988 to 1991, and no epidemic was detected in 1992 due to unfavorable climatic conditions (data not shown). The $\operatorname{Vr} 9$ was more frequent in the northern region than in the central region. A shift of virulence frequency was detected in the northern region, where Slejpner $(\operatorname{Yr} 9)$ was cultivated, but in the central region, where Récital $(\mathrm{Yr} \sigma)$ cultivation was higher than in the northern region, $\operatorname{Vr} 6$ remained dominant. The regional distribution of the cultivars determined the regional structure of the $P$. striiformis $\mathrm{f}$. sp. tritici population.

Detection of sources of durable resistance. This survey demonstrated the presence of some sources of durable resistance in 'Camp Rémy', 'Renan', 'Soissons' and 'Apache', which were found to be resistant for at least 10 years despite their cultivation on a large acreage (Table 2). Soissons and Apache were successively the most popular cultivars in France for 10 years. The resistance of Camp Rémy and Apache was expressed from the seedling stage while that of Soissons and Renan was expressed at the adultplant stage. $\mathrm{Yr}$ postulation at the seedling stage of Apache revealed the presence of $\mathrm{Yr} 7$ and $\mathrm{Yr} 17$, whereas no pathotype was widespread in France with combined virulences to both $Y r 7$ and $Y r 17$.

\section{Discussion}

A clearer understanding of the appearance of pathotypes with new virulences, and of their subsequent disappearance in line with the cultivation of corresponding resistance genes, and of the existence of host selection pressure at a regional level may be helpful in crop disease management. This survey has described the temporal dynamics of different virulence genes, explained by the distribution of resistance genes. The severity of stripe rust epidemics varied annually as a function of the deployment of resistant cultivars. Epidemic severity was consistently different between the north and the south of France over the study period, with epidemics being more frequent and severe in the former. This may have been due to more favorable environmental conditions for sporadic
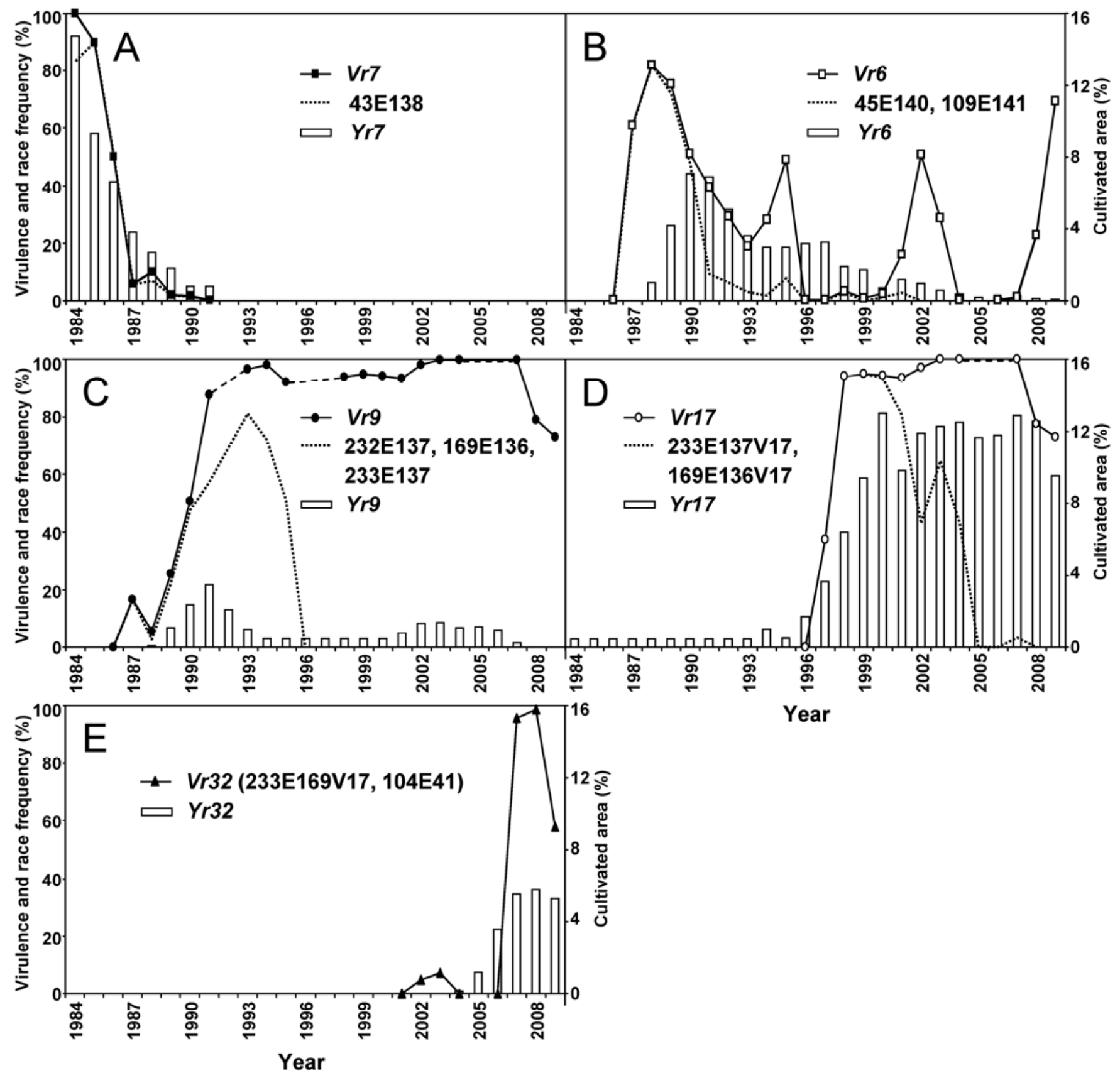

Fig. 4. Virulence frequencies of Puccinia striiformis f. sp. tritici A, Vr7; B, Vr6; C, Vr9; D, Vr17; and E, Vr32 (continuous lines) and the relative cultivated area of cultivars with the corresponding Yr gene (as bars) in northern France over the 25-year period. Dotted line represents the frequency of the races first detected with this virulence. 
disease development; more often in the north than in the south, where temperatures are generally higher and rainfall lower as required for $P$. striiformis f. sp. tritici (27). Additionally, the dominance of pathotype 6E16 in southern France coincided with the cultivation of the highly susceptible Victo, which bears no known $Y r$ genes and was widely cultivated (5 to $6 \%$ of total wheat production area in southern France during 1997 and 1998) because of its resistance to leaf rust, the prevailing type of wheat rust in southern France (27). The pathotype 6E16 was characterized as being exotic because of a virulence spectrum that markedly diverged from that of northern pathotypes (avirulent on $\mathrm{YrSd}$ and virulent on $Y r 7$ and $Y r 8$ ). This pathotype was also found in a sample from the durum wheat 'Regal', and its appearance seemed to be constant and characteristic of southern P. striiformis f. sp. tritici epidemics. Using molecular markers, the two populations were shown to be highly divergent at a genotypic level (25), with southern isolates belonging to a Mediterranean P. striiformis $\mathrm{f}$. sp. tritici genetic group (6) and northern isolates belonging to the northwestern European genetic group (25). This divergence may have resulted from both the cultivation of distinct cultivars and the adaptation of the pathogen to different climatic conditions (39).

The years that were epidemic-free were 1986, 1992, 1996, 2004, and 2006. These could be explained by environmental variables, and especially winter temperatures. One important measure was the cardinal temperatures (i.e., $0^{\circ} \mathrm{C}$ for infection) (49), which re- duced the viability of the inoculum. In 1986, $11 \%$ more days with minimum temperature below $0^{\circ} \mathrm{C}$ than the average over the 25 -year period in the north were recorded. Similarly, the absence of epidemics in 1992, in spite of the presence of both a susceptible host $(\operatorname{Yr} 9)$ and of the corresponding virulence $(\operatorname{Vr} 9)$, could be due to the extremely low winter temperatures in December 1991 and February 1992 (with $20 \%$ more days than average with minimum temperature below $0^{\circ} \mathrm{C}$ ). In 1996 and 2006, the percentages were 54 and $63 \%$, respectively, while, in 2004 , a dry spring (12\% relative humidity below the average) may account for the absence of an epidemic. On the other hand, in years with severe epidemics, such as 1999 , where there were $11 \%$ fewer days than average with minimum temperature below $0^{\circ} \mathrm{C}$, temperature was mild and relative humidity was high, conditions conducive to the disease (data not shown). In Europe, clonal survival in the absence of wheat during the summer can be explained by the presence of volunteers that were responsible for a "green bridge" in humid coastal regions and that constituted a source of primary inoculum for future epidemics (1). This may explain the absence of epidemics between 2003 and 2005, when severe drought conditions in the summer of 2003 could have caused the destruction of over-summering $P$. striiformis f. sp. tritici spores. The mean temperature in the north from June to September 2003 was the highest of the 25 years under study, $11 \%$ higher than the average temperature over the period. Overall, climatic factors played an important role in the survival and size of
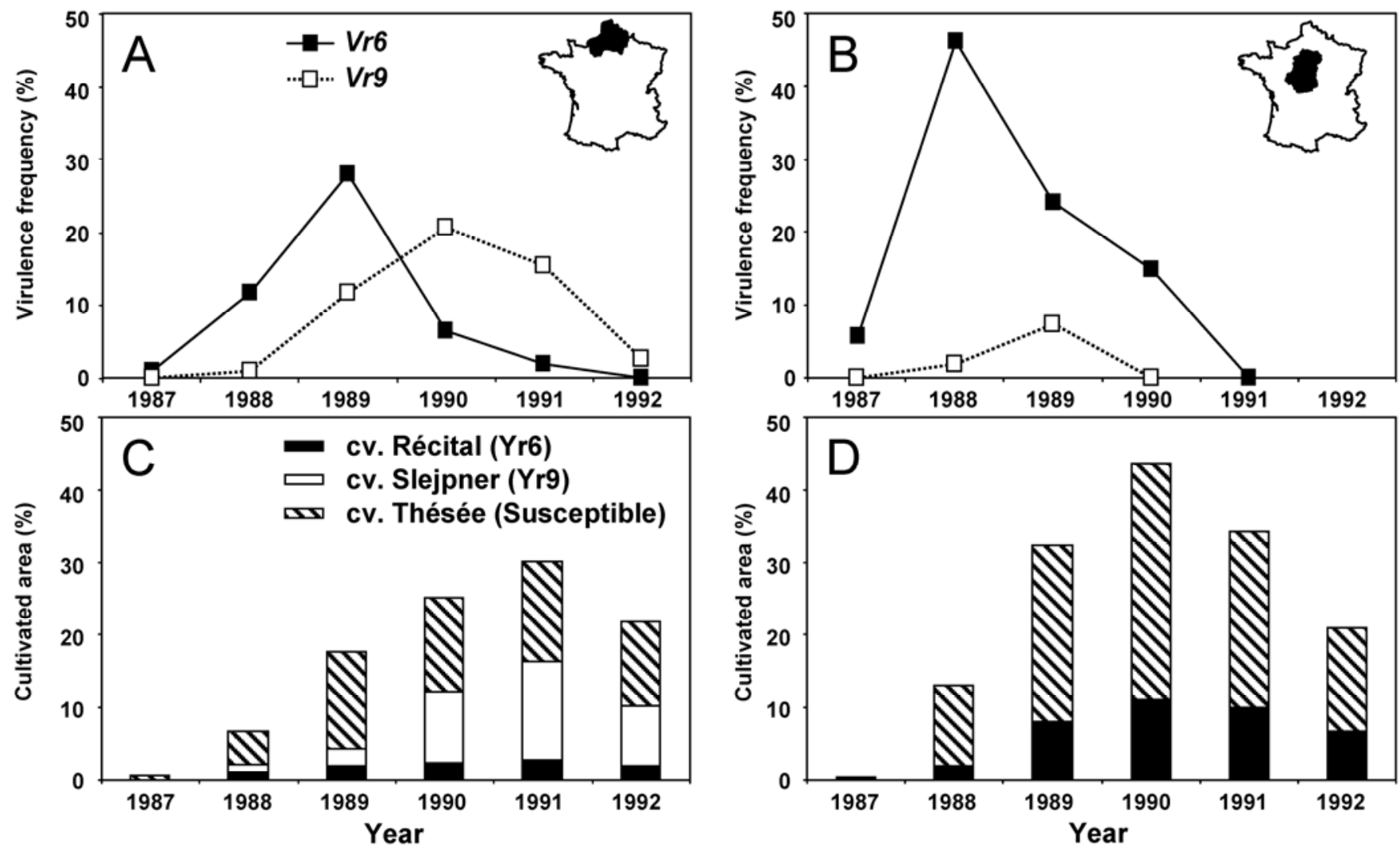

Fig. 5. Regional distribution of Puccinia striformis $\mathrm{f}$. $\mathrm{sp}$. tritici Vr6 and $\mathrm{Vr} 9$ virulence frequency in two regions of France (A, north and $\mathbf{B}$, center) and the proportionate distribution of 'Récital' (Yr6), 'Slejpner' (Yrg), and 'Thésée' (susceptible) in C, north and D, center of France. The two regions are indicated on the two maps of France (A and B).

Table 2. Cultivars with durable resistance according to the Puccinia striiformis f. sp. tritici survey performed during the period 1984 to 2009 in France

\begin{tabular}{|c|c|c|c|c|c|c|}
\hline Cultivar & $\begin{array}{c}\text { Registration } \\
\text { year }\end{array}$ & $\begin{array}{l}\text { Duration of cultivation } \\
\text { on major area }\end{array}$ & $\begin{array}{l}\text { Maximum annual } \\
\text { cultivar area }(\%)\end{array}$ & $\begin{array}{c}\text { Seedling } \\
\text { resistance genes }\end{array}$ & $\begin{array}{l}\text { Adult-plant } \\
\text { resistance genes }\end{array}$ & Reference \\
\hline Camp Rémy & 1980 & 1981-present & $\approx 11$ & QYr.inra-2BL & $\begin{array}{l}\text { QYr.inra- } 2 D S, \\
\text { QYr.inra-5BL.2 }\end{array}$ & 37 \\
\hline Renan & 1989 & 1990-present & $\approx 5$ & $\operatorname{Yr} 17$ & $\begin{array}{l}\text { QYr.inra-2BS, } \\
\text { QYr.inra-3BS, QYr.inra-6B }\end{array}$ & 17,22 \\
\hline Soissons & 1988 & 1989-present & $\approx 40$ & $Y r 3$ & Undetermined & 22 \\
\hline Apache & 1998 & 1999-present & $\approx 24$ & Yr7, Yr17 & QYr.inra-2AS2 & Unpublished data \\
\hline
\end{tabular}


the pathogen population, an issue outside of the scope of the current study.

The overall virulence dynamics and succession of different pathotypes in northern France were in accordance with the deployment of host resistance genes. Each epidemic in this region was characterized by the breakdown of a newly deployed or redeployed resistance gene. New pathotypes were detected in the years following the absence of epidemics, as in the case of $\operatorname{Vr} 6$ in 1987 (no epidemics in 1986), $\operatorname{Vr} 17$ in 1998 (no epidemics in 1996 to 1997), and $\operatorname{Vr} 32$ in 2007 (no epidemics in 2005 to 2006). A similar case was reported in Denmark $(28,29)$ where, following the absence of epidemics in 1996, pathotypes with a new virulence (Vr17) were detected and shown to be migrants from the United Kingdom. In the case of $\operatorname{Vr} 9$, however, the epidemics in northern France that occurred in 1989 followed the Vr6 epidemics without a break. Furthermore, pathotypes containing $\operatorname{Vr} 9$ remained at the same frequencies despite an epidemic-free year (1992). We also observed the acquisition of new virulences in the French P. striiformis $\mathrm{f}$. sp. tritici population, well described as a clonal population (25). This showed the adaptation of a clonal pathogen population to a host through mutation (as has been mentioned in the Australian P. striiformis f. sp. tritici population; 51) or migration (e.g., northwestern-European populations; 29). This followed the arms race between the host and the pathogen in nature $(16,38)$ but with human intervention where the cultivation on large areas of a resistant cultivar led to a "boom and bust cycle" (54). This resulted from the selection of a new mutant or migrant individual carrying the virulence to the newly deployed cultivar with resistance to the prevalent pathogen population. The frequency of this pathotype would increase in the overall population, discouraging cultivation of the cultivar in question. This was the case of the breakdown of $\operatorname{Yr} 9$ and $Y r 17$ in northwestern Europe (8) and of $\mathrm{YrlO}$ in the United States (13). The frequency of the pathotype would decrease with the deployment of a new cultivar resistant to this pathotype if there is a fitness cost. This is repeated for new pathotypes and resistance genes.
In the case of northern France, the evolution of pathotypes was based on their chronological appearance and virulence profiles, as well as on the deployment of $Y r$ genes (Fig. 6A) and the phylogenetic position of the pathotypes previously studied (25). This evolution followed a stepwise mutation model in a clonal population, as initially suggested for the evolution of pathotypes in Australia (55). Given that the most probable origin of the pathotypes in France was migration (11), the proposed scheme needs to be considered at the level of northwestern Europe. Virulence to a newly deployed $\mathrm{Yr}$ gene can be acquired by any existing pathotype clade but only one or two pathotypes were frequently found. As mentioned earlier, the epidemics in France were due to the successive breakdown of $\operatorname{Yr} 7, \operatorname{Yr} 6, \operatorname{Yr} 9, \operatorname{Yr} 17$, and $\operatorname{Yr} 32$ resistance genes. When new $Y r$ genes were deployed, pathotypes generally tended to evolve over time toward complexity and the acquisition of new virulences. However, in the present case, this adaptive process was not achieved through successive accumulation of new virulences in previously dominant pathotypes but through a more stochastic emergence of virulence in existing clonal lineages. The introduction of cultivars with two resistance genes (i.e., $\operatorname{Yr} 6+Y r 9$ and $Y r 6+Y r 17)$ led to the rapid selection of pathotypes with the two corresponding virulences (Fig. 6A). Thus, these new French pathotypes probably originated through migration rather than mutation in the existing population, because most of them displayed a virulence profile that differed for more than two virulences from previously prevailing pathotypes. In most cases, these pathotypes had already been described in other northwestern European countries such as the United Kingdom (9) and Denmark (28) (http:// www.eurowheat.org). Hovmøller et al. (29) described the case of Vrl7 epidemics at the European level, where pathotypes migrated in line with the cultivation of Yrl7-based cultivars from the United Kingdom to Denmark and then on to Germany and France (8). Migration played a major role in the P. striiformis $\mathrm{f}$. $\mathrm{sp}$. tritici structure, with the northern French populations belonging to a clonal northwestern European population $(25,29)$ while
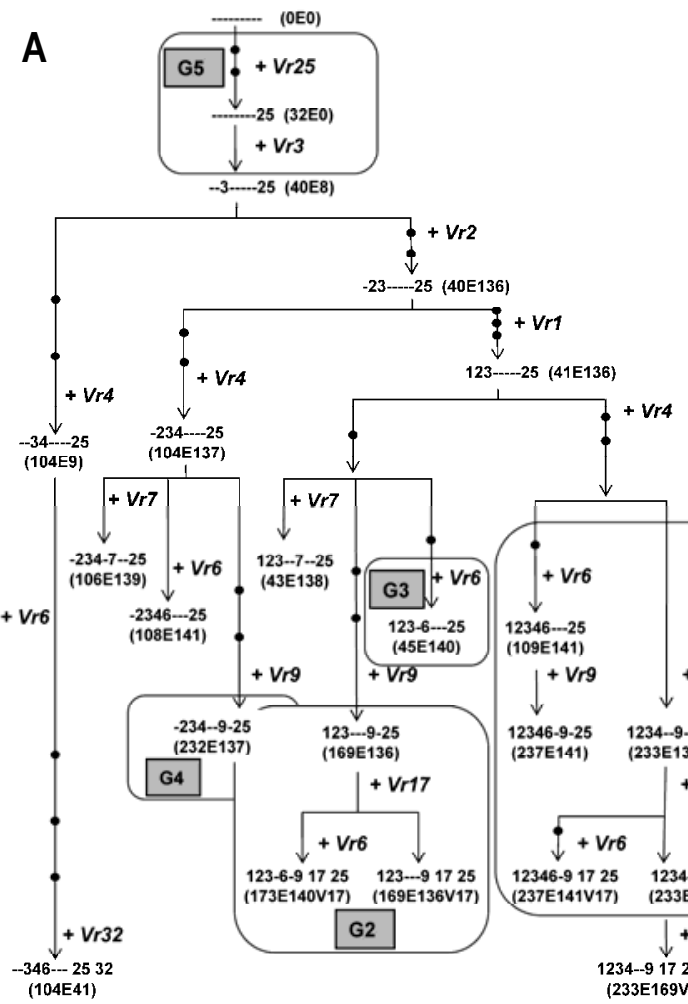

Year of first epidemics

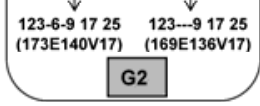

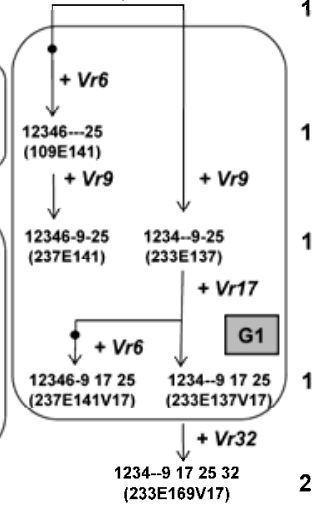

2007
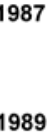

1998

(233E169V17)
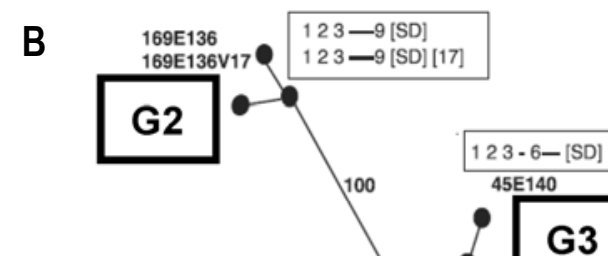

$<1984$
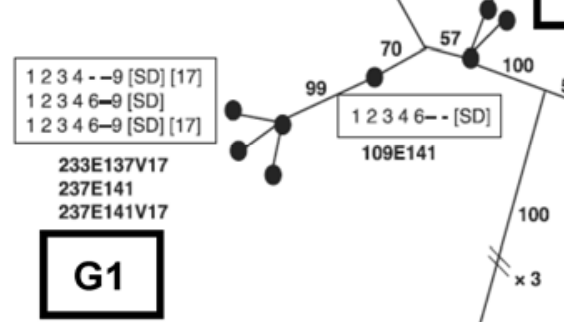

$32 \mathrm{EO}$

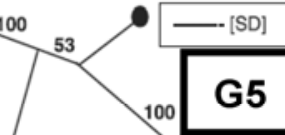

G5

Fig. 6. A, Hypothetical scheme for the pathotype evolution of Puccinia striiformis f. sp. tritici populations in northern France, based on virulence profile, chronological appearance, and pathotype prevalence. Virulence profiles included virulences Vr1, Vr2, Vr3, Vr4, Vr6, Vr7, Vr8, Vr9, Vr17, Vr25, and Vr32. Pathotypes are indicated in brackets. Genetic groups (G1 to G6) corresponded to B. Points indicate the number of amplified fragment length polymorphism (AFLP) markers that differed between the strains (25). B, Phylogenetic tree constructed with AFLP genetic data from Enjalbert et al. (25) used to compare genetic subgroups (G1 to G6). SD (Strubes Dickkof) virulence was shown in brackets. 
southern French populations belonged to a clonal Mediterranean population (6).

The phylogenetic tree (25) supported our hypothesis by grouping ancestral and descendant pathotypes within closed genetic groups (Fig. 6A). For example, we proposed that 109E141 isolates gave rise to 237E141 while placing 233E137V17 on another closed phylogenetic branch that gave rise to 237E141V17 and 233E137V17. This scheme took into account the acquisition of the same virulence independently in different genetic groups (i.e., $\operatorname{Vr} 17$ in G2 for 169E136V17 and in G1 for 233E137V17, the latter being the most frequent pathotype with $\operatorname{Vr17}$ ).

Although the frequency of a pathotype decreased in line with reduction in the cultivation of corresponding resistance gene-containing cultivars, virulence itself either disappeared or remained as an unnecessary virulence in other pathotypes carrying additional virulences. The loss of utility of host-specific resistance due to selection of the corresponding virulence was a major reason to question the use of such resistance genes. In our case, either the frequency of a critical virulence decreased due to a reduction of that specific $Y r$ gene (e.g., $V r 7$ and $V r 6$; Fig. 4A and B) or the critical virulence remained present in new pathotypes with additional virulence to the newly deployed resistance gene (as in the case of $\operatorname{Vr} 9$ and $\operatorname{Vr} 17$; Fig. 4C and D). This could be explained by the concept of the cost of virulence, the trade-off between the ability to establish an infection (i.e., virulence) and other characteristics of the parasite (e.g., within-host growth or the production of transmission stages; 10). Such virulence trade-offs penalized the pathogen in the absence of corresponding resistance genes (5). Because of this cost, all unnecessary virulence factors tend to be eliminated from a population, and pathotypes with virulences that matched the particular resistance of a host can be expected to be favored (54). Such a virulence cost was exemplified in the evolution of both $V r 7$ and Vr6. The latter has already been shown to be coupled with a substantial fitness cost (5). Virulences that did not generate costs could be expected to evolve as neutral traits in the absence of corresponding resistance genes, or may even tend to become fixed if the corresponding resistance gene is still cultivated to a lesser extent. This may be true for $\operatorname{Vr} 9$ and $V r 17$ in our case. $V r 9$ has been suggested to have compensated for its initial cost before becoming neutral (5). This seemed logical when considering the fact that all $V r 17$-harboring pathotypes carried $V r 9$. However, such frequency evolution must be analyzed with caution in a clonal population, because it can also be due to hitchhiking effects; a set of virulences or avirulences can increase in frequency because they are associated (in one or more pathotypes) to another resistance gene submitted to positive selection (29).

We reported here on the existence of a regional structure of $P$. striiformis f. sp. tritici populations in terms of $V r 6$ and $V r 9$ virulence frequency in line with the distribution of cultivars bearing $\operatorname{Yr} 6$ and $\operatorname{Yr} 9$ resistance genes. Although only a limited number of isolates were available, preventing an exhaustive survey, we were still able to determine a regional structure for $P$. striiformis f. sp. tritici, despite their ability for long-distance migration (11). The regional management of cultivars with different resistance genes could be a key component in landscape disease management because it can prevent the global spread of a major pathotype by reducing the genetic uniformity of the host. Strategies to increase the diversity of disease resistance genes could prevent the widespread prevalence of one or more major pathotypes $(46,57)$. Previously, the utilization of cultivar mixtures has been suggested as a means to increase intrafield diversity $(18,46)$. However, it has rarely been adopted on a large scale in intensive crop production because it leads to some complications arising from mixing cultivars with different cropping requirements. The concept of landscape management may be useful in this respect, because individual fields can be managed in a conventional manner while cultivars can be chosen to maximize the interfield diversity.

Both temporal and regional approaches should be adopted regarding host management in order to achieve durable rust resis- tance. Temporal alteration of cultivars containing different resistance genes may be useful to prevent the development of complex pathotypes. At the regional level, the cultivation of cultivars with different resistance genes would prevent the selection and uniform spread of a specific pathotype. On a larger scale, this could help to prevent the rapid spread of new pathotypes, as was observed for the highly aggressive, temperature-adapted, and closely related strains (44) that were first detected in the United States (45) and that spread rapidly to Australia (55) and Europe (31). However, these two strains have not been detected yet in northern France because of a lack of certain virulences ( $V r 3, V r 4, V r 17$, and $V r 25)$, against which the corresponding $\mathrm{Yr}$ genes are frequently present in grown cultivars (22). Similarly, at a continental level, the differential deployment of $Y r$ genes has resulted in pathotypes with different virulences; for example, the presence of $V r 9$ in Europe (21) and Asia (50) and its absence from the United States (21), and vice versa for $\operatorname{Vrl} 10$ (21). Thus, variability in terms of resistance genes at the regional, national, and continental levels, coupled with an alternation of cultivars over time and the use of partial resistance (issues addressed elsewhere; 2,3,48,50), could help to avoid successions of virulences and their fixation and, thus, achieve sustainable management of resistance. Similarly, the 25year survey demonstrated the presence of sources of durable resistance in four cultivars. Those cultivars had quantitative trait loci (QTLs) of resistance expressed at the adult-plant stage, and QTLs of resistance have now been selected from Camp Rémy (37) and Renan (17) and could be used in breeding programs to increase the durability of resistance to stripe rust. We suggested using adultplant resistance in addition to the major resistance genes in a samehost genotype, as observed for the cultivars with durable resistance, and diversifying the sources of resistance both temporally and regionally. The scale of landscape diversification could be the region, because we showed that the regional distribution of resistant cultivars affected the pathotype frequency.

\section{Acknowledgments}

Part of this research was carried out under the European COST 8.17 project (Agriculture and Biotechnology) between 1995 and 1999. This work received support from the European Integrated Project BIOEXPLOIT, FOOD-CT-2005513959 (2006 to 2011), and from the ENDURE project, Eurowheat (2008 to 2010), under the 6th Framework Programme. S. Ali was supported by a grant from the Higher Education Commission, the Government of Pakistan. We thank D. Caron, C. Maumené, and their colleagues from ARVALIS Institut du Végétal; our colleagues from Service Régional de la Protection des Végétaux; all the breeders who participated in the sampling of $P$. striiformis $\mathrm{f}$. sp. tritici isolates members of the COST 8.17 stripe rust subgroup (R. Bayles, R. Johnson [deceased], and M. Hovmøller) for their contribution; E. A. Milus for his constructive comments for the improvement of the manuscript; and our technical staff, notably L. Gérard and N. Galet.

\section{Literature Cited}

1. Ali, S., Leconte, M., Walker, A.-S., Enjalbert, J., and de Vallavieille-Pope, C. 2010. Reduction in the sex ability of worldwide clonal populations of Puccinia striiformis f. sp. tritici. Fungal Genet. Biol. 47:828-838.

2. Ali, S., Shah, S. J. A., Khalil, I. H., Rahman, H., Maqbool, K., and Ullah, W. 2009. Partial resistance to yellow rust in introduced winter wheat germplasm at the north of Pakistan. Aust. J. Crop Sci. 3:37-43.

3. Ali, S., Shah, S. J. A., and Rahman, H. 2009. Multi-locations variability in Pakistan for partial resistance in wheat to Puccinia striiformis West. tritici. Phytopathol. Mediterr. 48:269-279.

4. Andrivon, D., and de Vallavieille-Pope, C. 1995. Race diversity and complexity in selected populations of fungal biotrophic pathogens of cereals. Phytopathology 85:897-905.

5. Bahri, B., Kaltz, O., Leconte, M., de Vallavieille-Pope, C., and Enjalbert, J. 2009. Tracking costs of virulence in natural populations of the wheat pathogen, Puccinia striiformis f. sp. tritici. Online. BMC Evol. Biol. Online publication. doi:10.1186/1471-2148-1189-1126.

6. Bahri, B., Leconte, M., Ouffroukh, A., de Vallavieille-Pope, C., and Enjalbert, J. 2009. Geographic limits of a clonal population of wheat yellow rust in the Mediterranean region. Mol. Ecol. 18:4165-4179.

7. Bayles, R. A., Channell, M. H., and Stigwood, P. L. 1989. Yellow rust of wheat. Pages 11-17 in: U.K. Cereal Pathogen Virulence Survey, 1987. Annual Report, U.K. Cereal Pathogen Virulence Survey Committee, Cambridge.

8. Bayles, R. A., Flath, K., Hovmøller, M. S., and de Vallavieille-Pope, C. 2000. Breakdown of the $\operatorname{Yr} 17$ resistance to yellow rust of wheat in northern 
Europe- - a case study by the yellow rust sub-group of COST 817. Agronomie (Paris) 20:805-811.

9. Bayles, R. A., and Stigwood, P. L. 1999. Yellow rust of wheat. Pages 27-42 in: U.K. Cereal Pathogen Virulence Survey, 1998. Annual Report, U.K. Cereal Pathogen Virulence Survey Committee, Cambridge.

10. Brown, J. K. M. 2003. Little else but parasites. Science 299:1680-1681.

11. Brown, J. K. M., and Hovmøller, M. S. 2002. Aerial dispersal of fungi on the global and continental scales and its consequences for plant disease. Science 297:537-541.

12. Chen, X., Line, R. F., and Leung, H. 1993. Relationship between virulence variation and DNA polymorphism in Puccinia striiformis. Phytopathology 83:1489-1497.

13. Chen, X. M., Moore, M., Milus, E. A., Long, D. L., Line, R. F., Marshall, D., and Jackson, L. 2002. Wheat stripe rust epidemics and races of Puccinia striiformis f. sp. tritici in the United States in 2000. Plant Dis. 86:39-46.

14. Chisholm, S. T., Coaker, G., Day, B., and Staskawicz, B. J. 2006. Hostmicrobe interactions: shaping the evolution of the plant immune response. Cell 124:803-814.

15. Dangl, J. L., and Jones, J. D. 2001. Plant pathogens and integrated defence responses to infection. Nature 411:826-833.

16. Dawkins, R., and Krebs, J. R. 1979. Arm races between and within species. Proc. R. Soc. Lond. B Biol. Sci. 205:489-511

17. Dedryver, F., Paillard, S., Mallard, S., Robert, O., Trottet, M., Nègre, S., Verplancke, G., and Jahier, J. 2009. Characterization of genetic components involved in durable resistance to stripe rust in the bread wheat 'Renan'. Phytopathology 99:968-973.

18. de Vallavieille-Pope, C. 2004. Management of disease resistance diversity of cultivars of a species in single fields: controlling epidemics. C. R. Biol. 327:611-620.

19. de Vallavieille-Pope, C., Huber, L., Leconte, M., and Bethenod, O. 2002. Preinoculation effects of light quantity on infection efficiency of Puccinia striiformis and $P$. triticina on wheat seedlings. Phytopathology 92:13081314.

20. de Vallavieille-Pope, C., Huber, L., Leconte, M., and Goyeau, H. 1995. Comparative effects of temperature and interrupted wet periods on germination, penetration, and infection of Puccinia recondita f. sp. tritici and P. striiformis on wheat seedlings. Phytopathology 85:409-415.

21. de Vallavieille-Pope, C., and Line, R. F. 1990. Virulence of North American and European races of Puccinia striiformis on North American, world and European differentials. Plant Dis. 74:739-743.

22. de Vallavieille-Pope, C., Picard-Formery, H., Radulovic, S., and Johnson, R. 1990. Specific resistance factors to yellow rust in seedlings of some French wheat varieties and races of Puccinia striiformis Westend. in France. Agronomie (Paris) 10:103-113

23. de Vallavieille-Pope, C., Rouzet, J., Leconte, M., Delos, M., and Mistou, M. N. 2000. La rouille jaune du blé en France: des épidémies déclenchées par une nouvelle race, un hiver doux et un printemps humide. Phytoma 527:2229.

24. Duan, X., Tellier, A., Wan, A., Leconte, M., de Vallavieille-Pope, C., and Enjalbert, J. 2010. Puccinia striiformis f. sp. tritici presents high diversity and recombination in the over-summering zone of Gansu-China. Mycologia 102:44-53

25. Enjalbert, J., Duan, X., Leconte, M., Hovmøller, M. S., and de VallavieillePope, C. 2005. Genetic evidence of local adaptation of wheat yellow rust (Puccinia striiformis f. sp. tritici) within France. Mol. Ecol. 14:2065-2073.

26. Flor, H. H. 1971. The current status of the gene-for-gene concept. Annu. Rev. Phytopathol. 9:275-296.

27. Hau, B., and de Vallavieille-Pope, C. 2006. Wind-dispersed diseases. Pages 387-416 in: The Epidemiology of Plant Diseases, 2nd ed. B. M. Cooke, D. Gareth Jones, and B. Kaye, eds. Springer, Dordrecht, The Netherlands.

28. Hovmøller, M. S. 2001. Disease severity and pathotype dynamics of Puccinia striiformis f. sp. tritici in Denmark. Plant Pathol. 50:181-189.

29. Hovmøller, M. S., Justesen, A. F., and Brown, J. K. M. 2002. Clonality and long-distance migration of Puccinia striiformis $\mathrm{f}$. sp. tritici in north-west Europe. Plant Pathol. 51:24-32.

30. Hovmøller, M. S., Walter, S., Justesen, A. F., 2010. Escalating threat of wheat rusts. Science 329:369.

31. Hovmøller, M. S., Yahyaoui, A. H., Milus, E. A., and Justesen, A. F. 2008. Rapid global spread of two aggressive strains of a wheat rust fungus. Mol. Ecol. 17:3818-3826.

32. Huang, R., Kranz, J., and Welz, H. G. 1994. Selection of pathotypes of Erysiphe graminis f. sp. hordei in pure and mixed stands of spring barley. Plant Pathol. 43:458-470.
33. Johnson, R. 1992. Past, present and future opportunities in breeding for disease resistance, with examples from wheat. Euphytica 63:3-22.

34. Johnson, R., Stubbs, R. W., Fuchs, E., and Chamberlain, N. H. 1972. Nomenclature for physiologic races of Puccinia striiformis infecting wheat. Trans. Br. Mycol. Soc. 58:475-480.

35. Line, R. F. 2002. Stripe rust of wheat and barley in North America: a retrospective historical review. Annu. Rev. Phytopathol. 40:75-118.

36. Line, R. F., and Qayoum, A. 1991. Virulence, aggressiveness, evolution, and distribution of races of Puccinia striiformis (the cause of stripe rust of wheat) in North America, 1968-87. U. S. Dep. Agric. Tech. Bull. 1788.

37. Mallard, S., Gaudet, D., Aldeia, A., Abelard, C., Besnard, A. L., Sourdille, P., and Dedryver, F. 2005. Genetic analysis of durable resistance to yellow rust in bread wheat. Theor. Appl. Genet. 110:1401-1409.

38. Maor, R., and Shirasu, K. 2005. The arms race continues: battle strategies between plants and fungal pathogens. Curr. Opin. Microbiol. 8:399-404

39. Mboup, M., Bahri, B., Leconte, M., de Vallavieille-Pope, C., Katz, O., and Enjalbert, J. Genetic structure and local adaptation of European wheat yellow rust populations: The role of temperature-specific adaptation. Evolutionary Applications. In press.

40. Mboup, M., Leconte, M., Gautier, A., Wan, A. M., Chen, W., de Vallavieille-Pope, C., and Enjalbert, J. 2009. Evidence of genetic recombination in wheat yellow rust populations of a Chinese oversummering area. Fungal Genet. Biol. 46:299-307.

41. McDonald, B. A., and Linde, C. 2002. Pathogen population genetics, evolutionary potential, and durable resistance. Annu. Rev. Phytopathol. 40:349 379.

42. McIntosh, R. A., Dubcovsky, J., Rogers, W. J., Morris, C., Appels, R., and Xia, X. C. 2010. Catalogue of gene symbols. KOMUGI Integrated Wheat Science Database. http://www.shigen.nig.ac.jp/wheat/komugi/genes/symbol ClassList.jsp;jsessionid=689B192F53CED7CB561A9DC624FB9518.lb1,\% 202010

43. McNeal, F. H., Konzak, C. F., Smith, E. P., Tate, W. S., and Russel, T. S. 1971. A uniform system for recording and processing cereal research data. Pages 34-121 in: U. S. Agric. Res. Serv. Bull. Washington, DC.

44. Milus, E. A., Kristensen, K., and Hovmøller, M. S. 2009. Evidence for increased aggressiveness in a recent widespread strain of Puccinia striiformis f. sp. tritici causing stripe rust of wheat. Phytopathology 99:89-94.

45. Milus, E. A., Seyran, E., and McNew, R. 2006. Aggressiveness of Puccinia striiformis f. sp. tritici isolates in the south-Central United States. Plant Dis. 90:847-852.

46. Mundt, C. C., and Browning, J. A. 1985. Genetic diversity and cereal rust management. Pages 527-560 in: The Cereal Rusts. A. P. Roelfs and W. R. Bushnell, eds. Academic Press, Orlando, FL.

47. Office National Interprofessionnel des Grandes Cultures. 2008. Répartition des variétés-récoltes 1999-2008 (blé tendre, orge, blé dur, triticale) Technical Report: Les Cahiers de l'ONIGC. France Agrimer. Paris.

48. Pathan, A. K., and Park, R. F. 2007. Evaluation of seedling and adult plant resistance to stem rust in European wheat cultivars. Euphytica 155:87-105.

49. Rapilly, F. 1979. Yellow rust epidemiology. Annu. Rev. Phytopathol. 17:5973.

50. Singh, R. P., William, H. M., Huerta-Espino, J., and Rosewarne, G. 2004 Wheat rust in Asia: meeting the challenges with old and new technologies. In: New Directions for a Diverse Planet: 4th Int. Crop Sci. Congr. Brisbane, Australia.

51. Steele, K. A., Humphreys, E., Wellings, C. R., and Dickinson, M. J. 2001 Support for a stepwise mutation model for pathogen evolution in Australasian Puccinia striiformis f. sp. tritici by use of molecular markers. Plant Pathol. 50:174-180.

52. Stubbs, R. W. 1985. Stripe rust. Pages 61-101 in: The Cereal Rusts, Diseases, Distribution, Epidemiology and Control. A. P. Roelfs and W. R. Bushnell, eds. Academic Press, London.

53. USDA. 2010. Catalog of Rust Resistance Genes in Small Grains http://www.ars.usda.gov/Main/docs.htm?docid=10342.

54. Van der Plank, J. E. 1968. Disease Resistance in Plants. Academic Press, New York and London.

55. Wellings, C. R. 2007. Puccinia striiformis in Australia: a review of the incursion, evolution and adaptation of stripe rust in the period 1979-2006. Aust. J. Agric. Res. 58:567-575.

56. Wellings, C. R., and McIntosh, R. A. 1990. Puccinia striiformis f. sp. tritici in Australasia: pathogenic changes during the first 10 years. Plant Pathol 39:316-325.

57. Wolfe, M. S., and Barrett, J. A. 1980. Can we lead the pathogen astray. Plant Dis. 64:148-155. 